\title{
WILLIAM CLANCY, 1923-82
}

William Clancy was not much over thirty and had already served as an editor at Commonweal and as religion editor at Newsweek when he came to the Council on Religion and International Affairs (then The Church Peace Union) to launch a unique venturc in American publishing.

January, 1958, as Bill characterized it in his first Worldview editorial, was "a time of troubles." And indeed the list of problems he recited-new weapons of destruction, Soviet challenges, dissension in the AIliance, cconomic dislocations-reads startlingly like a carte de jour. This new journal, he said, will be concerned with the broad area of ethics and forcign affairs.... At all times, among all nations, a tension between ethics and forcign policy scems inevitable." Worldview "will nol 'preach,' but it will insist-sometimes explicitly, more often implicitly"- that "the West's perennial tradition, which is deeply, essentially rooted in the values of the Judeo-Christian classical humanist view of man and society [is] relevant to, even normative for, the survival of any world worth saving."

Bill Clancy left Worldview in the fall of 1961 to seck holy orders in Rome. He later established The Oratory in Piltsburgh and became its first Provost, minister- ing to sludents in the Pittsburgh area and devoting himself to study and thought. "A work of the intelligence," he had called Worldvien', and to the same work he dedicated himself here.

On the occasion of his leavelaking from Worldview, Bill had stressed that "ours is an altempt to understand rather than an altempt to propagandize." In words that would secm to have been uttered just this morning he counseled patience: "At a time in history such as ours...the temptation toward the slogans of the Right- 'Get rid of the Communists'- or of the Left'Get rid of the bomb'-are especially strong. Then too men who have a religious commitment often think that religion somehow provides an easy answer, has a word to say that will solve all of the world's difficultics. Even while the barbarians are beating on the gates of the city, we must cultivate patience... [T] his attempt is often difficult to explain to a public impatient for solutions, but it is indispensable for our civilization, and only the fool or the philistine can fail to sce its value."

Those of us who knew Father Clancy personally and others who knew him solely as the one who laid the foundation for Worldric's's mission mourn his death from cancer at the carly age of fifty-nine. how a certain rhetoric affects the lives of citizens. Instead. the Ottaways have sculpted a body of beliefs and values, called them "Afrocommunism," and purport 10 find them in threce or morc African socictics. The reality looks a lot more like pragmatic opportunism to kecp shaky regimes and rulers in power than a vision of a new socicty. (wivi)

\section{Briefly Noted}

\section{THE MAN WHO LEADS THE CHURCH: AN ASSESSMENT OF POPE JOHN PAUL II by John Whale, Peter Hebblethwaite, and Staff of the London Sunday Times}

(Harper and Row; 271 pp.; S10.95)

There is much to enjoy here, if one is not put off by other aspects of this journalistic stitching. Best of all, it is a mix of reporters' notebooks on the odd and somelimes wondrous things that happence offstage during the pope's journeys to Poland, Ireland, the U.S., Latin America, and elsewhere. Worst of all, it claims to bc a serious "assessment" of the person and work of John Paul II.

The assessment doesn't work because the authors seem unable to make up their minds; or perhaps there are just too muny authors. The recurring judgment is that John Paul II is a iruly remarkable man who has, regrellably, turned in a "clcarly conservative" direction. He is encouraging a "new papolatry" that is cssentially hostile to change, especially on questions of women's rights and sexual ethics. At the same time, it is acknowledged that the pope envisions his mission as one of helping to bring about a major international realignment of powers shaping the modern world. As the authors (or an author) Say, "In this vast [globall perspective. comprehending past, present and future, American and European agonizing over birth control and ordination of women seemed merely an irrelevant distraction." At another point we are told that this conservative pope is more accuratcly called a "radical" because he has starlled the world with a witness in which the Christian faith "is his norm, his only norm."

This book might have been more helpful if it had more consistently acknowicdged that John Paul's course simply does not fit such secular thoughi'slots as liberal and conservalive. Right or wrong, he is advocating a quite new direction. The evidentec of that, contra their dominant assessment, is to be found in the authors' often engaging narration of what John Paul has said and done to date. -Richard Jolm Nemhaus

\section{CONTRIBUTORS}

Berel l.ang is a momber of the Department of Philosophly at the University of Colorado. Boulder.

Gorton Zalm, Emerims Professor of Sociology' at Brestom Universits, is now associated with the Pax Christi C'mer oll Conscic'ne' and W'ar in C'ambridge.

Srophen J. Rosen is Professor of Economics at Edward Williams College' of Fairlcigh Dickinson University and a labor arbirranor.

Girald Fremud, a Worldvicw Comsriburing Elitor. is Vice Presielem of the Jolm D. \& Calherine" T. Mac'Arlhur Foundation and Director of its Prize Fellows Prostam.

Aaron Segal, former editor of Africa Report, is (')-aulhor of The Traveler's Africu. 